Pesq. Vet. Bras. 30(4):351-357, abril 2010

\title{
Morphological features and vascularization study of caprine cyclic corpus luteum ${ }^{1}$
}

\author{
Maria Tereza M. Miranda de Moura², Vanessa Uemura da Fonseca ${ }^{3}$, \\ Naisandra Bezerra da Silva², Maria de Lourdes Freitas², Osiel Benedito de \\ Almeida ${ }^{2}$, Hugo Alexandre de Oliveira Rocha ${ }^{4}$, Paula de Carvalho Papa ${ }^{3}$ and \\ Carlos Eduardo Bezerra de Moura ${ }^{2^{*}}$
}

\begin{abstract}
Miranda-Moura M.T.M., Fonseca V.U., Silva N.B., Freitas M.L., Almeida O.B., Rocha H.A.O., Papa P.C. \& Moura C.E.B. 2010. Morphological features and vascularization study of caprine cyclic corpus luteum. Pesquisa Veterinária Brasileira 30(4):351-357. Departamento de Morfologia, Centro de Biociências, Universidade Federal do Rio Grande do Norte, Av. Salgado Filho s/n, Campus Lagoa Nova, Natal, RN 59072970, Brazil. E-mail: mouraeduard@cb.ufrn.br

Corpus luteum is a temporary endocrine gland that regulates either the estrous cycle and pregnancy. It presents extreme dependency on the adequate blood supply. This work aims to evaluate goat corpus luteum (CL) vascular density (VD) over the estrous cycle. For that purpose, 20 females were submitted to estrus synchronization/ovulation treatment using a medroxyprogesterone intra-vaginal sponge as well as intramuscular (IM) application of cloprostenol and equine chorionic gonadotrophine (eCG). After sponge removal, estrus was identified at about $72 \mathrm{hs}$. Once treatment was over, female goats were then subdivided into 4 groups ( $n=5$ each) and slaughtered on days 2, 12, 16 and 22 after ovulation (p.o). Ovaries were collected, withdrawn and weighted. CL and ovaries had size and area recorded. Blood samples were collected and the plasma progesterone (P4) was measured through RIA commercial kits. The VD was $24.42 \pm 6.66,36.26 \pm 5.61$, $8.59 \pm 2.2$ and $3.97 \pm 1.12$ vessels $/ \mathrm{mm}^{2}$ for days $2,12,16$ and 22 p.o, respectively. Progesterone plasma concentrations were $0.49 \pm 0.08,2.63 \pm 0.66,0.61 \pm 0.14$ and $0.22 \pm 0.04 \mathrm{ng} / \mathrm{ml}$ for days $2,12,16$ e 22 p.o, respectively. Studied parameters were affected by the estrous cycle phase. Values greater than 12 p.o were observed. In the present work we observed that ovulation occurred predominantly in the right ovary $(70 \%$ of the animals), which in turn presented bigger measures than the contra lateral one. There is a meaningful relationship between the weight and size of the ovary and these of $C L(r=0.87$, $r=0.70$, respectively, $p<0.05$ ). It is possible to conclude that morphology of goat's ovaries and plasma progesterone concentration changed according to estrous cycle stages. We propose these parameters can be used as indicators of CL functional activity.
\end{abstract}

INDEX TERMS: Corpus luteum, goat, anatomy, vascular density, progesterone.

\footnotetext{
${ }^{1}$ Received on April 23, 2008.

Accepted for publication on December 18, 2009.

2 Departamento de Morfologia, Centro de Biociências, Universidade Federal do Rio Grande do Norte (UFRN), Av. Salgado Filho s/n, Campus Lagoa Nova, Natal, RN 59072-970, Brazil. Corresponding author: mouraeduard@cb.ufrn.br

${ }^{3}$ Departamento de Cirurgia, Setor de Anatomia, Faculdade de Medicina Veterinária e Zootecnia, Universidade de São Paulo (USP), Av. Orlando Marques de Paiva 87, São Paulo, SP 05508-270, Brazil.

${ }^{4}$ Departamento de Bioquímica, Centro de Biociências, UFRN, Natal, RN.
}

RESUMO.- [Características morfológicas e estudo da
vascularização do corpo lúteo cíclico de cabras ao lon-
go do ciclo estral.] O corpo lúteo é uma glândula endócrina
temporária que regula tanto o ciclo estral quanto a prenhez,
apresentando extrema dependência de aporte sanguíneo
adequado. Objetivaram-se avaliar mudanças morfométricas
dos ovários e densidade vascular (DV) dos corpos lúteos
(CL) de cabras ao longo do ciclo estral (AOLC). Vinte ani-
mais foram submetidos ao tratamento para indução/sincro-
nização do estro, usando esponjas intravaginais com 
medroxiprogesterona, associadas a aplicações intramusculares de cloprostenol e gonadotrofina coriônica eqüina. Após remoção das esponjas, o estro foi identificado em aproximadamente de $72 \mathrm{~h}$. Concluído o tratamento, as cabras foram subdivididas em 4 grupos ( $n=5$ cada) para abate nos dias 2, 12, 16 e 22 após ovulação (p.o.). Posteriormente, foram retirados os ovários e realizadas as mensurações de peso, tamanho e área do órgão e dos CL. Amostras de sangue foram coletadas e a progesterona sérica (P4) mensurada utilizando-se RIA convencional. A DV média dos CL AOLC foi $24,42 \pm 6,66$; $36,26 \pm 5,61$; $8,59 \pm 2,2$ e $3,97 \pm 1,12$ vasos $/ \mathrm{mm} 2$ para os dias $2,12,16$ e 22 p.o., respectivamente. A concentração média de $\mathrm{P} 4$ foi de $0,49 \pm 0,08 ; 2,63 \pm 0,66 ; 0,61 \pm 0,14$ e $0,22 \pm 0,04 \mathrm{ng} / \mathrm{ml}$ para os dias 2, 12, 16 e 22 p.o., respectivamente. Os parâmetros em estudo também se mostraram afetados pela fase do ciclo estral, sendo observados os maiores $(p<0,05)$ valores no dia 12 p.o. Neste experimento, a ovulação ocorreu predominantemente no ovário direito ( $70 \%$ dos animais), o qual apresentou medidas maiores que o contralateral. Observou-se ainda alta correlação significativa entre o peso do ovário e o do $C L(r=0,87 ; p<0,05)$ e entre o tamanho destes órgãos $(r=0,70 ; p<0,05)$. Conclui-se que, a morfologia dos ovários de cabras e a concentração sérica de progesterona variam em função da fase do ciclo estral e podem ser utilizadas como parâmetro na avaliação funcional do órgão.

TERMOS DE INDEXAÇÃO: Corpo lúteo, caprino, anatomia, densidade vascular, progesterona.

\section{INTRODUCTION}

In the last years, biotechnological research has focused on the development of techniques and procedures enabling increase of reproductive efficiency in economical important animals. Morphological studies describing the organization of the female reproductive system as well as histological and physiological changes related to the estrous cycle are the basis of reproductive oriented research.

Among economical important species, the goat has gained a lot of attention since the start of putative increase, according to Food and Agriculture Organization of the United Nations (FAO 2000), goat population is estimated in 700 millions, from which $92 \%$ are distributed in tropical and subtropical underdeveloped areas. Even though goat herds are spread all over the world, they usually are treated empirically and with low levels of technology.

In order to assure the success of goats' biotechnical exploitation, it is necessary to achieve reproductive efficiency, which can be measured by an increase in the pregnancy number during the female reproductive life. Thus, it is fundamental to understand the estrous cycle characteristics of the species, especially in events related to the development, life span and regression of the corpus luteum (CL).

The corpus luteum is one endocrine organ showing a limited, short existence. It plays a central role in the regulation of estrous cycle and pregnancy by secreting progesterone, which should be maintained in appropriate levels in mammals in order to achieve a successful reproduction (Stocco et al. 2007).

Angiogenesis is an essential event for CL formation and maintenance as well as for progesterone production (Yan et al. 1998). Besides, it is known that there is an intimate correlation between $\mathrm{CL}$ vascularization, blood flow and hormone production (Stormshak et al. 1963, Kobayashi et al. 2001). CL angiogenesis is controlled by a number of growth factors including VEGF (vascular endothelial), FGF (fibroblasts grown factor), TGF- $B$ (transforming growth factor), FGF (fibroblast growth factor), PDGF (platelet derived growth factor), interleukin-8 and angiopoietin-1 (Stocco et al. 2007).

The morphometrical characterization of the reproductive organs is important to highlight variations occurring in ovarian structures responsible for gametogenesis and esteroidogenesis during estrous cycle and pregnancy. During the estrous cycle there are growth and atresia of a variable follicle number (Ginther et al. 1989, Roche et al. 1991), formation and regression of corpus luteum (Kastelic et al. 1990), phenomena which influence directly morphological characteristics of the ovary. The morphological characteristics of the ovary can also be useful to verify the pathological presence of cists and tumors as well as to determine the presence of a cyclic ovarian activity and even to estimate the probable cycle phase, allowing one to infer on the animal's fertility status (Nascimento et al. 2003).

The hypothesis was that goat ovary and CL morphological changes reflect reproductive functional status. To test this hypothesis, this work aimed to describe ovarian macroscopic morphological parameters, to determine CL vascular density and plasma progesterone concentrations (as a marker of functional status) in this species.

\section{MATERIALS AND METHODS}

Animals and synchronization treatment/estrous induction. During the months of March and April 2006, 20 cross breed adult goats presenting a recorded healthy reproductive history, were confined in the Pedra Vermelha Farm, Lages, Rio Grande do Norte, Brazil. Animals were submitted to estrous induction/ synchronization treatment as described by Freitas \& Lopes Jr (2002). Briefly, at day zero (d 0) of treatment, animals received intravaginally $60 \mathrm{mg}$ of medroxiprogesterona acetate sponges (MAP, Progespon ${ }^{\circledR}$ Tecnopec, São Paulo). After seven days (d 7 ), each animal received $300 \mathrm{UI}$ of equine chorionic gonadotrophine (eCG, Novormon ${ }^{\circledR}$ Tecnopec, São Paulo, Brazil) as well as $5 \mathrm{ml}$ of cloprostenol (Prolise ${ }^{\circledR}$ Tecnopec, São Paulo) intramuscularly. After $48 \mathrm{~h}$ (d 9), sponges were removed and the estrus was observed within $72 \mathrm{~h}$ and considered the day of ovulation.

Ovarian morphometrical samples and corpus luteum collection. The goats were divided into four groups ( $n=5$ in each group) and slaughtered on days 2, 12, 16 and 22 post ovulation (p.o.). The ovaries were colletected immediately after evisceration, dissected and measured using a paquimeter precision scale. The symmetry of the organs was respected. 
Luteal tissue mass was calculated using the ellipse area defined by the highest and lowest diameter of the CL (Nascimento et al. 2003). Blood samples were collected by puncture of the jugular vein and centrifuged at $4000 \mathrm{rpm}$, for $5 \mathrm{~min}$ under $5^{\circ} \mathrm{C}$ and kept at $20^{\circ}$ until plasma progesterone was assessed by RIA.

CL microscopic examination. CL was dissected and cut into pieces of $5 \mathrm{~cm}^{3}$, which were fixed in $4 \%$ phosphate buffered formalin solution, $\mathrm{pH} 7.2$ for 24 hours. Paraffin embedding was preceded by dehydration in increasing ethanol concentrations as well as xylene clarification.

Slices with $6 \mu \mathrm{m}$ from paraffin blocks were obtained and stained with hematoxiline-eosine (HE) and Schiff's periodical acid (PAS) reaction.

Vascular density determination. Vascular density (expressed in number of vessels per area in $\mathrm{cm}^{2}$ ) was determined as proposed by Ferreira-Dias et al. (2006). Six $\mu$ m slices were stained by PAS, which strongly reacts with basal membrane carbohydrates and is widely used as a marker for endothelial cells (Luna et al. 1992).

For each animal, 16 fields $\left(0.77 \mathrm{~cm}^{2}\right.$ area) were counted. These were chosen randomly through 6 histological sections, using a 400x magnification and an image reader software (Imagen-pro Plus ${ }^{\circledR}$ ). All vessels in luteal tissue were equally evaluated (arterioles, venules e capillaries).

Plasma progesterone concentration. Progesterone concentration in plasma sample was evaluated using a commercial kit (DSL-3400â, Diagnostic Systems Laboratories, USA). The standard curve was obtained by $P_{4}$ increasing concentrations diluted in a phosphate gel buffer (PBS-G). The radioactive [I-125] progesterone was diluted at $70 \%$ in PBS-G and the primary antibody (rabbit origin) and the precipitation liquid (goat origin) were deluded at $60 \%$ in PBS-G. As positive control, diluted follicular fluid raging from low to medium and high progesterone content was used.

The results were calculated using the Riasmart program. The intra and inter-assay variation coefficient were $6.14 \%$ and $5.34 \%$, respectively.

Statistical analysis. All the results were expressed as average \pm standard deviation. Statistical comparison was done using ANOVA. The multiple comparison Tukey-Kramer test was employed when necessary. Differences were considered if $p \leq 0.05$. Correlation regarding size and format of the ovary and the $C L$ as well as the vascular density and progesterone concentrations were analyzed using Pearson correlation coefficient.

\section{RESULTS}

\section{Morphometry of the ovary and the corpus luteum}

The ovaries of goats showed an ellipsoid shape and apparently did not present color changes between the phases. In Table 1 it can be seen that the morphometric parameters of goats' ovaries are affected by the estrous cycle. Higher values were seen on day 12 post ovulation (p.o.). Positive correlation was observed between the size of the ovary and the $C L(r=0.70, p<0.05)$, and between the weight of the ovary and that of $C L(r=0.87, p<0.05)$. CL morphology showed modifications along the estrous cycle as can be seen in Figure 1. The CL of the goat presented a fast growth, showed by the increase of about twice its weight between days 2 and 12. Therefore, that growth exceeded half of the goat's estral cycle (Table 1). The regression of the CL was marked by the decrease in its weight and size observed by day 16 p.o.

In this experiment, the ovulation occurred more frequently in the right ovary $(70 \%$ of the animals) that is larger than the contralateral organ; however these differences were not statistically significant (Table 1).

\section{Microscopical features of goats' corpus luteum during the estrous cycle}

The evaluation of the photomicrographs of goats' CL showed that their microscopic structure also changed along estrous cycle (Fig.2).

Hemorrhagic body (d 2 p.o.). The corpus luteum showed a defined lobular structure, separated by septa of connective tissue that contains most of the blood vessels.

Mature corpus luteum (d 12 p.o.). CL was characterized by the presence of luteal cells containing large, central and spherical nuclei indicative of a secretory activity. The cytoplasm shows many granules and intercellular spaces were reduced.

Regression of the corpus luteum (d 16 p.o.). There was a massive invasion of connective tissue and this phase is characterized by cellular disorganization and large interstitial spaces. The luteal cells show small nuclei with membrane retraction and the presence of dense peripheral granulations, which correspond to the fragmented chromatin.

Corpus albicans (d 22 p.o.). In this phase, the luteal cells are rarely found and there is a predominance of fibrous connective tissue. Blood vessels are also scarce, however, when present, they are surrounded by concentric layers of fibroblasts.

\section{Vascular density along the estrous cycle}

Average vascular density of the corpus luteum of goats, expressed in number of vessels per square millimeter, was influenced by the estrous cycle phase $(p<0.05$; Fig. 3$)$.

Table 1. Morphometric measures of the ovary and Corpus luteum (CL) of the goats during oestrus cycle

\begin{tabular}{cccccccccc}
\hline & \multicolumn{2}{c}{ Size of ovary $(\mathrm{cm})$} & & \multicolumn{2}{c}{ Weight of ovary $(\mathrm{g})$} & & \multicolumn{3}{c}{ Corpus luteum } \\
\cline { 2 - 3 } \cline { 7 - 8 } Day p.o. & Right & Left & & Right & Left & & Size $(\mathrm{cm})$ & Weight $(\mathrm{g})$ & Area $\left(\mathrm{cm}^{2}\right)$ \\
\hline 02 & $1.64 \pm 0.21^{\mathrm{a}}$ & $1.75 \pm 0.27^{\mathrm{a}}$ & & $1.14 \pm 0.84^{\mathrm{a}}$ & $1.15 \pm 0.24^{\mathrm{a}}$ & & $0,80 \pm 0,19^{\mathrm{a}}$ & $0,32 \pm 0,21^{\mathrm{a}}$ & $1,61 \pm 0,56^{\mathrm{a}}$ \\
12 & $2.02 \pm 0.16^{\mathrm{a}}$ & $1.96 \pm 0.11^{\mathrm{a}}$ & & $1.58 \pm 0.58^{\mathrm{b}}$ & $1.51 \pm 0.24^{\mathrm{b}}$ & & $1.34 \pm 0.24^{\mathrm{b}}$ & $0.84 \pm 0.04^{\mathrm{b}}$ & $4.09 \pm 0.78^{\mathrm{b}}$ \\
16 & $1.90 \pm 0.31^{\mathrm{a}}$ & $1.80 \pm 0.25^{\mathrm{a}}$ & & $1.39 \pm 0.58^{\mathrm{ab}}$ & $1.24 \pm 0.34^{\mathrm{ab}}$ & & $0.86 \pm 0.29^{\mathrm{a}}$ & $0.34 \pm 0.26^{\mathrm{a}}$ & $2.05 \pm 1.22^{\mathrm{a}}$ \\
22 & $1.40 \pm 0.41^{\mathrm{a}}$ & $1.64 \pm 0.11^{\mathrm{a}}$ & & $0.96 \pm 0.04^{\mathrm{a}}$ & $0.90 \pm 0.07^{\mathrm{a}}$ & & $0.76 \pm 0.23^{\mathrm{a}}$ & $0.27 \pm 0.15^{\mathrm{a}}$ & $1.20 \pm 0.46^{\mathrm{a}}$
\end{tabular}

Mean \pm SD, $a-b$ Different letters in the same column differ $(p<0.05)$. 


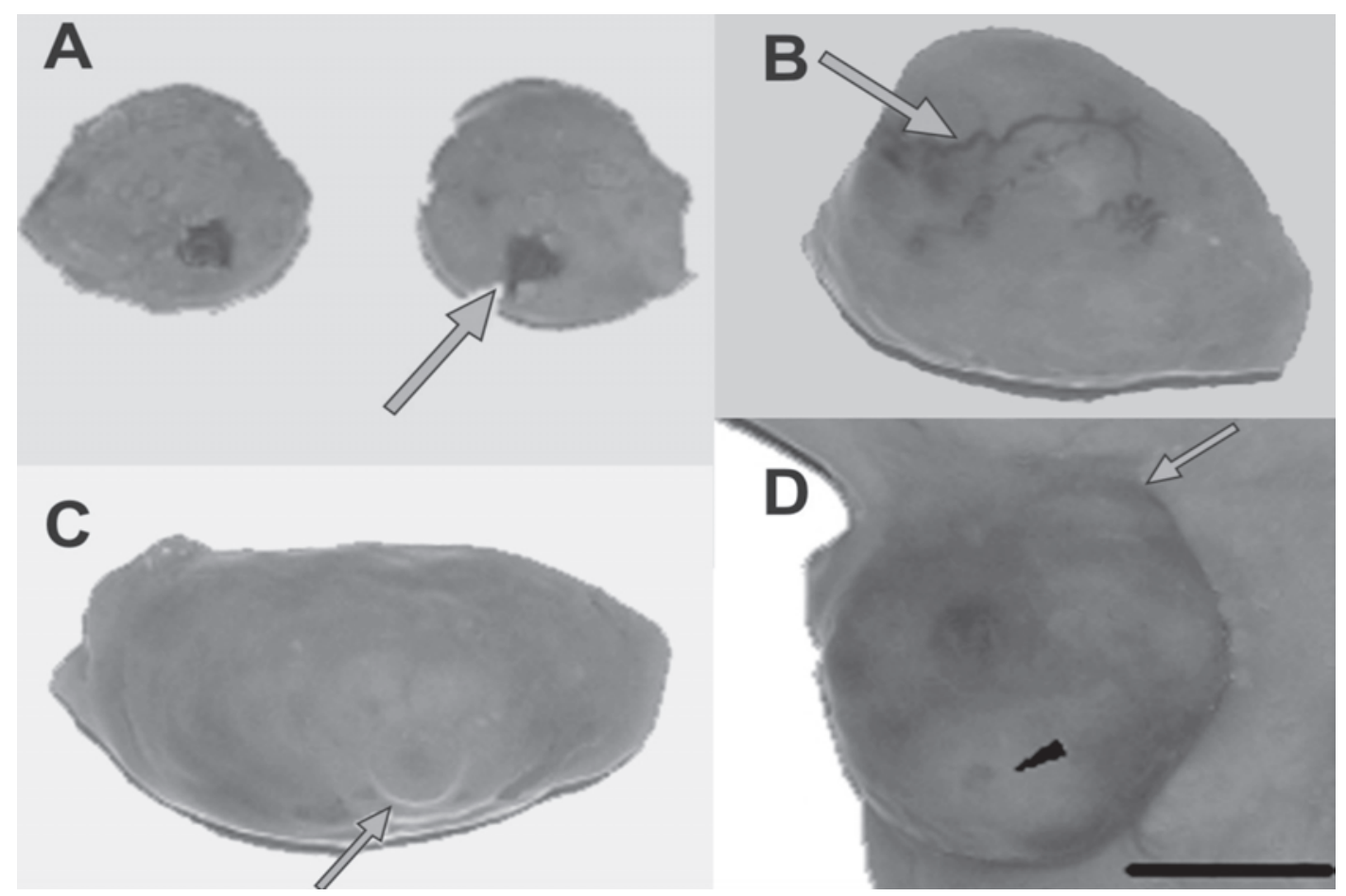

Fig.1. Corpus luteum (CL) of a goat during the estrous cycle. (A) CL on day 2 post ovulation (p.o.); its color is dark red or brown. (B) CL on day 12 (p.o.). Highly vascularized surface $(\rightarrow)$. (C) CL on day 16 (p.o.). In this phase the CL does not present blood vessels in its boundary and shows a pale yellow color. (D) CL on day 22 p.o. The CL is white colored ( $(\mathbf{)})$ and on the ovary it is possible to observe the presence of a big follicle. Bar: $10 \mathrm{~mm}$.
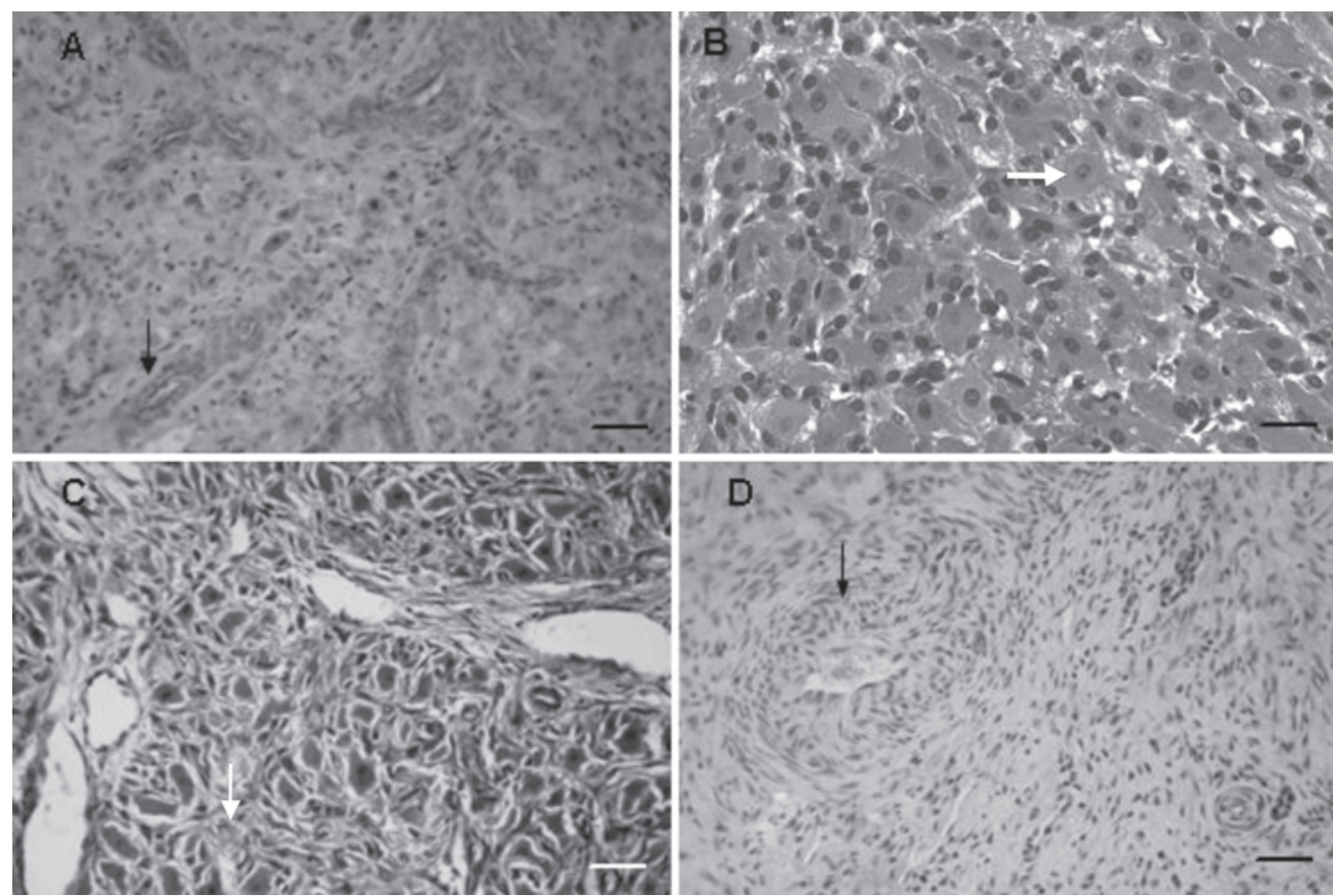

Fig.2. Photomicrographs showing the goat CL during different phases of estrous cycle. (A) Hemorrhagic body (d 2 p.o.). Blood vessel in the interlobular septa $(\rightarrow)$. (B) Mature corpus luteum (d 12 p.o.). Luteal cells showing round central nuclei $(\rightarrow)$. (C) Regression of the corpus luteum (d 16 p.o.). Disorganization of the luteal cells and invasion of connective tissue $(\rightarrow)$. (D) Corpus albicans (d 22 p.o.). Blood vessels surrounded by concentric layers of fibroblasts. HE. Bar: $40 \mu$. 


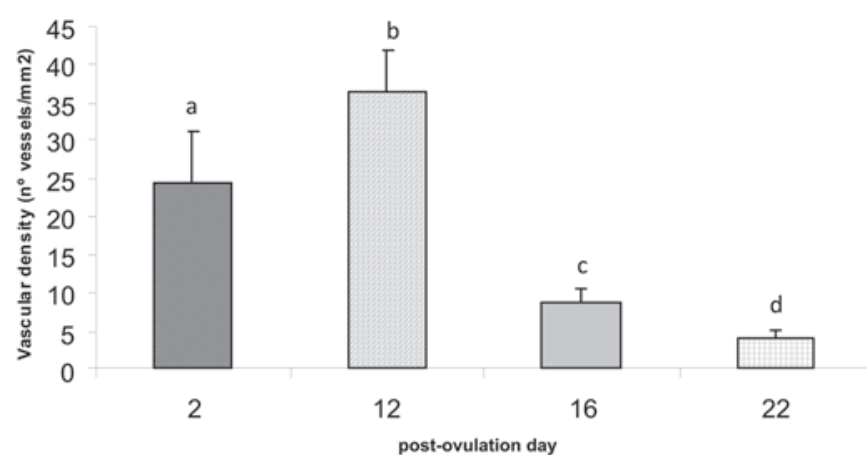

Fig.3. Vascular density of goats' corpus luteum in different phases of the estrous cycle. Values are means \pm standard deviation ( $n=5$ per studied phase). ${ }^{a-d}$ Indicate significant $(p<0.05)$ differences among estrous cycle phases.

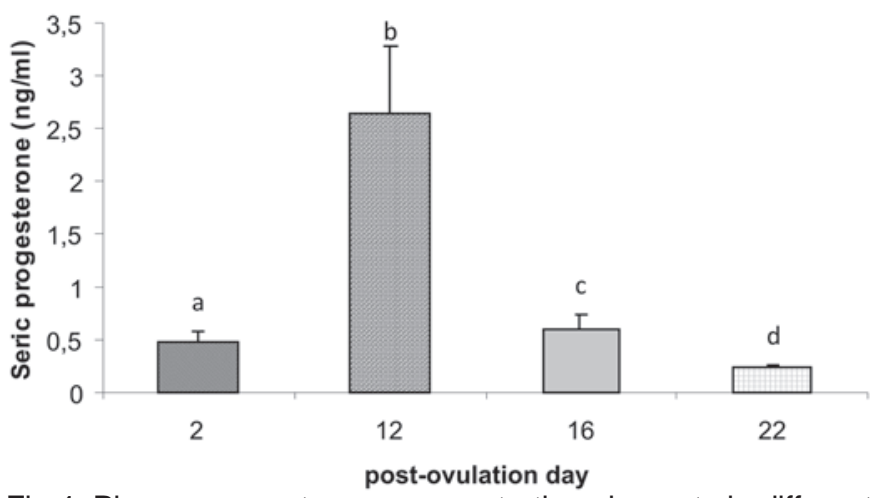

Fig.4. Plasma progesterone concentrations in goats in different phases of the estrous cycle. Values are means \pm standard deviation ( $n=5$ per studied phase). ${ }^{a-d}$ Indicate significant $(p<0.05)$ differences among estrous cycle phases.

Data showed the occurrence of a $33 \%$ increase in vascular density from day 2 to day 12 p.o. A $76 \%$ reduction in VD was observed from day 12 to 16 p.o., and further $54 \%$ decrease up to the $22^{\text {th }}$ day p.o., culminating with the formation of the corpus albicans (CA).

\section{Plasma progesterone concentrations}

In the present study, plasma progesterone concentrations in goats was meaningfully different among the phases of the estrous cycle $(p<0.05)$ as can be observed in Figure 4. The highest concentrations occurred on day 12 p.o. A reduction of progesterone values was observed on day 16 p.o., followed by a decrease to nadir values on day 22 p.o.

There was a positive correlation between the vascular density and plasma progesterone concentrations in the different phases of the estrous cycle $(r=0.81, p<0.05)$.

\section{DISCUSSION}

Parameters related to the morphology of $C L$ are often used to estimate the estrous cycle stage (Ireland et al. 1980, Nascimento et al. 2003, Ferreria-Dias et al. 2006). The present study revealed significant effect of the estral cycle phase on the weight, size and area of the goats' CL $(p<0.05)$. Changes of the CL macroscopic and microscopic structure observed during the estrous cycle matched plasma progesterone concentrations, a parameter used to evaluate functional activity of the organ (Stocco et al. 2007).

In goats, the growth period of the CL surpassed the half of the estral cycle (on the $12^{\text {th }}$ day p.o.). There was a progressive decrease observed near the $16^{\text {th }}$ day p.o., culminating in smallest size and weight values on the $22^{\text {th }}$ day p.o., the corpus albicans stage. Similar findings were described for bovine $C L$, which showed rapid weight gain between the $2^{\text {nd }}$ and $12^{\text {th }}$ day p.o., and remained constant until the $16^{\text {th }}$ day p.o., then the morphologic regression began and measures were reduced to a half within 36 hours (Koos 1993). In bubaline, that increase was about 33 times in weight between the $2^{\text {nd }}$ and $15^{\text {th }}$ day of the ovarian cycle and after the regression (approx. on the $17^{\text {th }}$ day p.o.) there was a reduction to one-third in relation to mature $\mathrm{CL}$, and the $\mathrm{CA}$ reached the equivalent to one fourth of $\mathrm{CL}$ (El-Sheikh et al. 1967). In sheep, that also possesses an ovarian cycle of 21 days, on average, as well as in goats, that growth did not surpass the $10^{\text {th }}$ day p.o. and begin to decline from the $12^{\text {th }}$ day, accompanied by a reduction of CL secretory activity (Warbritton 1934).

In goats the size of the ovary also varied depending on the stage of the estrous cycle, certainly influenced by changes in the $\mathrm{CL}$. This is confirmed before the positive correlation found between these parameters $(r=0.81$, $\mathrm{p}<0.05)$. Moreover, the weight of $\mathrm{CL}$ is a significant fraction of the total weight of the ovary. Similar findings were described by Nascimento et al. (2003) when studying morphometric changes of the ovary and the CL of cows. These authors stated that this fact favors monitoring the reproductive activity of the animal, when $C L$ are internalized or not projected on the surface of the ovary, because the gonad size will help the identification of animals that present cyclic ovarian activity (Sprecher et al. 1989, Ribadu et al. 1994). Viana et al. (1999) observed that animals' ovaries with signs of luteal activity, but without a typical $\mathrm{CL}$, showed estrus within the 21 subsequent days, similar to animals that had $\mathrm{CL}$ identified by palpation.

The size, weight and the luteinic area had maximum value at day 12 p.o., coinciding with the phase in which the $C L$ reaches its functional maturity, confirmed by the increased production of progesterone in this phase (Kastelic et al. 1990), whereas the lowest values were observed on days 2 and 22 that correspond to luteogenesis and the CA phase (Ireland et al. 1980, Menon et al. 1994).

The vascular density (VD) is another important parameter, which reflects vascularization of the tissue and, consequently, its blood perfusion level (Dharmarajan et al. 1985, Asahara et al. 1995). The study of VD in the CL of goats confirmed that, apart from the macroscopic and microscopic changes in the luteal structure, changes in the vascular network during the estrous cycle were observed, which reflected the functional activity of the organ. Similar results were previously reported in cattle and bubaline (Zheng et al. 1993, Modlich et al. 1996, Moura et al. 2003). 
Changes in vascularization of goat $C L$ during the estrous cycle, suggest the involvement of angiogenic factors, produced during the luteal development, but not yet identified in this species. The main regulating factors of the luteal angiogenesis are: vascular endothelial growth factor (VEGF), basic fibroblast growth factor (bFGF) and angiopoetins, which promote the proliferation and migration of endothelial cells, as well the vascular growth in the ovarian tissues of several species (Stocco et al. 2007)

The expression of these angiogenic factors and their receptors is influenced by gonadotrophic hormones such as LH, hCG and FSH (Fraser et al. 2005). Probably, the highest vascular densities found in animals on days 2 and 12 p.o. can be explained by increased proliferation and migration of endothelial cells in response to increased expression of VEGF and its receptors stimulated by high concentrations of LH during the luteinization (Fraser et al. 2005). Other hormones also influence the expression of these angiogenic factors. Previous reports showed that the $\mathrm{PGF}_{2 a}$, a luteolytic hormone produced by the epithelial cells of the endometrium promotes the decrease in mitogenic activity of endothelial cells (Ferreira-Dias et al. 2006). This may be not just due to inhibition of the synthesis of these factors, but also by promoting the release of antiangiogenic factors, such as the angiostatin and endostatin (Maisonpierre et al. 1997, Cervantes \& Garcia 2002). Decrease in vascular density of the $C L$ on day 16 p.o. probably occurred due to $\mathrm{PGF}_{2 a}$. Previous studies demonstrated that this hormone binds to specific receptors on endothelial cells that release endotheline-1 (ET-1) (Milvae 2000, Pate \& Keyes 2001). This protein acts as a potent vasoconstrictor, inhibits the esteroidogenic activity, reducing the blood flow during the initial luteolysis by arteriolar constriction, leading to hypoxia and thus, to cell apoptosis (Milvae et al. 1996, Milvae 2000, Pate \& Keyes 2001).

High concentrations of $\mathrm{P}_{4}$ in goats occurred on day 12 p.o., confirming the phase of mature CL (d 12 p.o.), in which higher vascular density was observed. Increase in blood delivery as well as secretion of $\mathrm{P}_{4}$ in this phase was seen in other species (Jablonka-Shariff et al. 1993, Reynolds et al. 1994, Papa et al. 2007). In this study the decrease of $\mathrm{P}_{4}$ concentration confirmed the occurrence of functional luteolysis on day 16 p.o., followed by structural luteolysis, culminating in CA formation (d 22 p.o.), when the concentration of this hormone reduces to basal levels (Neuvians et al. 2004). The decrease of the $P_{4}$ secretion coincides with the reduction of vascular density on day 16 p.o. Similar results were previously described for bubaline (Moura et al. 2003). According to Milvae et al. (1996) the decrease of progesterone concentration at this stage is most commonly due to decreased ability of the esteroidogenic capacity of the individual luteal cells and the luteal blood flow. The PGF 2 á would than connect to specific receptors placed in large-sized luteal cells (LLCs) (Anderson et al., 2001), where they adhere to the stimulatory $G$ protein, inducing the activation of the phospholipase C (PLC) that through a signaling way stimulates the catalytic activity of the enzyme $\mathrm{Ca}^{++}$dependent protein kinase $C$ (PKC). It is believed that the PKC mediates many anti-esteroidogenic actions of the $\mathrm{PGF}_{2 a}$ in the LLCs (Niswender et al. 2000).

\section{CONCLUSIONS}

Gross changes in appearance of corpus luteum and morphometric parameters (area, weight, size) can be used to estimate stages of the estrous cycle in goats.

The luteal vascular density may influence progesterone production, which can be used as a functional parameter to evaluate the organ.

\section{REFERENCES}

Anderson L.E., Wu Y., Tsai S. \& Wiltbank M.C. 2001. Prostaglandin $F_{2 \alpha}$ receptor in the Corpus luteum: Recent information on the gene, messenger ribonucleic acid, and protein. Biol. Reprod. 64(4):10411047.

Asahara T., Bauters C., Zheng L.P., Tekeshita S., Estamenha S., Ferrara N., Symes J.F. \& Isner J.M. 1995. Synergistic effect of factor of growth of vascular endothelial and fibroblast growth basic factor in angiogenesis in alive. Circulation 92(9):11365-11371.

Cervantes M.C.E. \& Garcia A.R. 2002. Angiogenesis in reproductive physiology: Follicular development, formation and maintenance of the Corpus luteum. Gynecol. Obstetr. Mex. 70:17-27.

Dharmarajan A.M., Bruce N.W. \& Meyer G.T. 1985. Quantitative ultrastructural characteristics relating to transport between luteal cell cytoplasm and blood in the corpus luteum of the pregnant rat. Am. J. Anat. 172(1):87-99.

El-Sheikh A.S., Sakla F.B. \& Amin S.O. 1967. Changes in the destiny and progesterone content of luteal tissue in the Egyptian buffalo during the oestrous cycle. J. Endocrinol. 39(2):163-171.

Ferreira-Dias G., Bravo P.P. \& Mateus L. 2006. Microvascularization and angiogenic activity of equine corpora lutea throughout the estrous cycle. Domest. Anim. Endocrinol. 30(4):247-259.

FAO 2000. Situación de los mercados de productos básicos. 1997-1998. Food and Agriculture Organization, Rome. [Cited 2006.6.19]. Available from: <www.fao.org.br>.

Fraser H.M., Wilson H., Morris K.D., Swanston I. \& Wiegand S.J. 2005. Vascular endothelial growth factor trap suppresses ovarian function at all stages of the luteal phase in the macaque. J. Clin. Endocrinol. Metab. 90(10):5811-5818.

Freitas V.J.F. \& Lopes Jr E.S. 2002. Controle do estro e da ovulação em caprinos, p.57-67. In: Gonçalves P.B.D., Figueiredo J.R. \& Freitas V.J.F. (Eds), Biotécnicas Aplicadas à Reprodução Animal. Varela, São Paulo.

Ginther O.J., Kastelic J.P. \& Knopf L. 1989. Intraovarian relationships among dominant and subordinate follicles and the Corpus luteum in heifers. Theriogenology 32(5):787-795.

Ireland J., Murprphee R.L. \& Coulson P.B. 1980. Accuracy of predicting stages of bovine estrous cycle by gross appearance of the Corpus luteum. J. Dairy Sci. 63(1):155-160.

Jablonka-Shariff A., Grazul-Bilska A.T., Redmer D.A. \& Reynolds L.P. 1993. Growth and cellular proliferatin of ovine corpora lutea throughout the estrous cycle. Endocrinology 133(4):1871-1879.

Kastelic J.P., Pierson R.A. \& Ginther O.J. 1990. Ultrasonic morphology of corpora lutea and central luteal cavities during the estrous cycle and early pregnancy in heifers. Theriogenology 34(3):487- 498.

Kobayashi S., Berisha B., Amselgruber W.M. \& Schams D. 2001. Production and localization of angiotensin II in the bovine early Corpus 
luteum: A possible interaction with luteal angiogenic factors and prostaglandin F2 $\alpha$. J. Endocrinol. 170(2):369-380.

Koos R.D. 1993. Ovarian angiogenesis, p.433-453. In: Adashi E.Y. \& Leung P.C.K. (Ed.), The Ovary. Raven Press, New York.

Luna L.G. 1992. Polysaccharides and mucopolysaccharides, p.364-398. In: Ibid. (Ed.), Histopathologic Methods and Color Atlas of Special Stains and Tissue Artifacts. American Histolabs Inc., Gaithersburg, MD.

Maisonpierre P.C., Suri C., Jones P.F., Bartunkova S., Wiegand S.J., Radziejewski C., Compton D., McClain J., Aldrich T.H., Papadopoulos N., Daly T.J., Davis S., Sato T.N. \& Yancopoulos G.D. 1997. Angiopoietin-2, a natural antagonist for Tie2 that disrupts in vivo angiogenesis. Science. 277(5322):55-60.

Menon M., Peegel H. \& Menon K.M. 1985. Lipoprotein augmentation of human chorionic gonadotropin and prolactin stimulated progesterone synthesis by rat luteal cells. J. Steroid. Biochem. 22(1):79-84.

Milvae R.A. 2000. Inter-relationships between endothelin and prostaglandinF2 ${ }_{a}$ in corpus luteum function. Rev. Reprod. 5:1-5.

Milvae R.A., Hinckley S.T. \& Carlon J.C. 1996. Luteotropic and luteolytic mechanisms in the bovine corpus luteum. Theriogenology 45(7):13271349.

Modlich U., Kaup F.J. \& Augustin H.G. 1996. Cyclic angiogenesis and blood vessel regression in the ovary: Blood vessel regression during luteolysis involves endothelial cell detachment and vessel occlusion. Lab. Invest. 74(4):771-780.

Moura C.E.B., Campos D.B., Pereira F.T.V., Oliveira M.F., Miglino M.A. \& Papa P.C. 2003. Density of Corpus luteum from superovaluted and control buffalo cows. Acta Microsc. 12:43-44

Nascimento A.A., Pinheiro N.L., Sales A. \& Viana J.H.M. 2003. Correlação morfométrica do ovário de fêmeas bovinas em diferentes estádios reprodutivos [Morphometric correlation of the ovary of bovine females on different reproductive stages]. Braz. J. Vet. Res. Anim. Sci. 40(2):126-132.

Neuvians T.P., Berisha B. \& Schams D. 2004. Vascular endothelial growth factor (VEGF) and fibroblast growth factor (FGF) expression during induced luteolysis in the bovine Corpus luteum. Mol. Reprod. Dev. 67(4):389-395.

Niswender G.D., Juengel J.L., Silva P.J., Rollynson M.K. \& Mclntush E.W. 2000. Mechanisms controlling the function and life span of the Corpus luteum. Physiol. Rev. 80(1):1-29.

Papa P.C., Moura C.E.B., Artoni L.P., Fatima L.A., Campos D.B., Mar- ques Jr J.E., Baruselli P.S., Binelli M., Pfarrer C. \& Leiser R. 2007. VEGF system expression in different stages of estrous cycle in the corpus luteum of non-treated and superovulated water buffalo. Domest. Anim. Endocrinol. 33(4):379-389.

Pate J.L. \& Keyes P.L. 2001. Immune cells in the Corpus luteum: Friends or foes? Reproduction 122(5):665-676.

Reynolds L.P., Grazul-Bilska A.T., Killilea S.D. \& Redmer D.A. 1994. Mitogenic factors of corpora lutea. Progr. Growth Factor Res. 5(2):159175.

Ribadu A.Y., Ward W.R. \& Dobson H. 1994. Comparative evaluation of ovarian structures in cattle by palpation per rectum, ultrasonography and plasma progesterone concentration. Vet. Rec. 135(19):452-7.

Roche J.F. \& Boland M.P. 1991. Turnover of dominant follicles in cattle of different reproductive states. Theriogenology 35(1):81-90.

Sprecher D.J., Nebel R.L. \& Whitman S.S. 1989. The predictive value, sensitivity and specificity of palpation per rectum and transrectal ultrasonography for the determination of bovine luteal status. Theriogenology 31(6):1165-1172.

Stocco C., Telleria C. \& Gibori G. 2007. The molecular control of Corpus luteum formation, function and regression. Endocrinol. Rev. 28(1):11749.

Stormshak F., Inskeep E.K., Lynn J.E., Pope A.L. \& Casida L.E. 1963. Progesterone levels in corpora lutea and ovarian effluent blood of the ewe. J. Anim. Sci. 22:1021-1026.

Viana J.H.M., Winkler B., Ferreira A.M., Sá, W.F. 1999. Estimativa do desempenho reprodutivo na estação de monta com base em prévia avaliação da atividade ovariana por palpação retal. [Estimation of reproductive performance on the amounts based on prior assessment of ovarian activity by rectal palpation]. Revta Bras. Ciênc. Vet. 6(2): 88-91.

Warbritton V. 1934. The cytology of the corpora lutea of the ewe. J. Morphol. 56(1):186-202.

Yan Z., Neulen J., Raczek S., Weich H.A., Keck C., Grunwald K. \& Breckwoldt M. 1998. Vascular endothelial growth factor (VEGF)/ vascular permeability factor (VPF) production by luteinized human granulose cells in vitro: A paracrine signal in Corpus luteum formation. Gynecol. Endocrinol. 56(3):149-153.

Zheng J., Redmer D.A. \& Reynolds L. 1993. Vascular development and heparin-binding growth factors in the bovine Corpus luteum at several stages of the estrus cycle. Biol. Reprod. 49(6):1117-1189. 